\title{
PENGARUH PENERAPAN METODE PAIR CHECKS TERHADAP HASIL BELAJAR SISWA MATA PELAJARAN PENDIDIKAN AGAMA ISLAM (PAI) SEKOLAH MENENGAH PERTAMA (SMP) NEGERI 3 PALIMANAN KABUPATEN CIREBON
}

\author{
Oleh : \\ ${ }^{1}$ Nimas Kuraeni, ${ }^{2}$ Mahfud, ${ }^{3}$ Iwan \\ Pendidikan Agama Islam (PAI) FITK IAIN Syekh Nurjati Cirebon \\ Email: ${ }^{1}$ nimaskuraeni@syekhnurjati.ac.id \\ ²mahfud@syekhnurjati.ac.id \\ 3iwan@syekhnurjati.ac.id
}

\begin{abstract}
ABSTRAK
Pair Checks merupakan metode pembelajaran berkelompok atau berpasangan yang menuntut kemandirian dan kemampuan siswa dalam menyelesaikan persoalan dan memberi penilaian. Hasil belajar adalah hasil yang diperoleh siswa setelah terjadinya proses pembelajaran yang ditunjukan dengan nilai tes yang diberikan guru setiap selesai memberikan materi pelajaran pada satu pokok bahasan. penelitian ini bertujuan untuk mengetahui Pengaruh Penerapan Metode Pair Checks Terhadap Hasil Belajar Siswa Mata Pelajaran Pendidikan Agama Islam (PAI) Sekolah Menengah Pertama (SMP) Negeri 3 Palimanan Kabupaten Cirebon. Teknik pengumpulan data yang digunakan adalah: Observasi, Wawancara, Angket, Tes dan studi dokumentasi. Sedangkan Teknik analisis data yang digunakan adalah uji validitas, reabilitas, normalitas, prosentase, korelasi product moment, koefisien determinan dan Uji hipotesis. Hasil penelitian yang diperoleh ialah mencapai nilai korelasi $r_{x y}=0,710$ yang menunjukkan pada korelasi yang kuat/tinggi karena berada
\end{abstract}

\section{Jurnal Pendidikan Agama Islam} IAIN Syekh Nurjati Cirebon 
pada interval 0,700 - 0,900. Adapun pengaruh penerapan metode Pair Checks (variabel X) dalam meningkatkan hasil belajar (variabel Y) di SMPN 3 Palimanan Kabupaten Cirebon adalah sebesar 50,41 \% sedangkan sisanya 49,59 \% dipengaruhi oleh faktor lain yang tidak diteliti dalam penelitian ini.

Kata Kunci : Metode Pembelajaran, Metode Pair Checks Dan Hasil Belajar

\begin{abstract}
Pair Checks are a group or pairing learning method that demands students' independence and ability to solve problems and give judgment. Learning outcomes are the results obtained by students after the learning process which is shown by the value of the test given by the teacher after each lesson material is given to one subject. This study aims to determine the effect of the application of Pair Checks Method to Learning Outcomes of Students of Islamic Education (PAI) Subjects in Palimanan 3 Junior High School (SMP) Negeri 3 Cirebon District. Data collection techniques used are: Observation, Interview, Questionnaire, Test and study documentation. While the data analysis technique used is the test of validity, reliability, normality, percentage, product moment correlation, determinant coefficients and hypothesis testing. The results of the research obtained are reaching the rxy correlation value $=0.710$ which shows a strong / high correlation because it is in the interval 0.700 - 0.900. The influence of the application of the Pair Checks method (variable $X$ ) in improving learning outcomes (variable Y) in Palimanan 3 Junior High School in Cirebon Regency is $50.41 \%$ while the remaining $49.59 \%$ is influenced by other factors not examined in this study.
\end{abstract}

Keywords: Learning Method, Pair Checks Method and Learning Outcomes 


\section{A. PENDAHULUAN}

Pendidikan pada dasarnya merupakan suatu proses pembelajaran. Pembelajaran adalah upaya atau proses guru memberikan pelajaran kepada peserta didik secara aktif dan efektif untuk mencapai tujuan pembelajaran yang telah ditetapkan, dan dilakukan secara sengaja, terprogram, tersistem, terfasilitasi, terbimbing, terarah, dan terorganisasi. ${ }^{1}$ Untuk memudahkan proses pembelajaran diperlukan berbagai metode pembelajaran yang bervariasi .

Metode pembelajaran merupakan salah satu komponen yang berperan penting dalam kegiatan pembelajaran. Metode pembelajaran adalah suatu cara yang digunakan untuk melaksanakan rencana yang sudah disusun atau kegiatan belajar mengajar dalam bentuk praktis untuk mencapai tujuan pembelajaran. ${ }^{2}$ Pemilihan metode yang tepat akan lebih memudahkan guru dalam menyampaikan materi dan memudahkan siswa dalam memahami materi pembelajaran dan akan berpengaruh pada kegiatan belajar siswa dan hasil belajar siswa. Salah satu metode yang dapat diterapkan dalam pembelajaran Pendidikan Agama Islam (PAI) dan diharapkan mampu meningkatkan hasil belajar yaitu metode Pair Checks.

Pair Checks merupakan metode pembelajaran dimana siswa saling berpasangan dan menyelesaikan persoalan yang diberikan. Metode ini mengedepankan bekerja kelompok dalam memahami materi yang sedang dipelajari. ${ }^{3}$ Hasil belajar ialah suatu kinerja yang diindikasikan sebagai suatu kemampuan yang telah diperoleh setelah melalui suatu proses pembelajaran.

\footnotetext{
${ }^{1}$ Dirman dan Cicih Juarsih, Kegiatan Pembelajaran Yang Mendidik (Jakarta: PT Rineka Cipta, 2014), 8.

${ }^{2}$ Helmiati, Model Pembelajaran (Yogyakarta: Aswaja Pressindo, 2012), 20.

3 Aris Shoimin, Model Pembelajaran Inovatif dalam Kurikulum 2013 (Yogyakarta: Ar-Ruzz Media, 2017), 119.
} 
Setiap kegiatan belajar yang dilakukan peserta didik akan menghasilkan perubahan-perubahan dalam dirinya, yang oleh bloom dan kawan-kawan dikelompokkan kedalam kawasan, yakni sikap, pengetahuan dan keterampilan. ${ }^{4}$

Sebelum proses pembelajaran dilakukan tentunya guru sudah menyiapkan materi dan metode pembelajaran dengan baik, dengan harapan proses belajar berjalan lebih baik dan hasil belajar akan meningkat dari sebelumnya. Namun pada kenyataannya peneliti menemukan fakta bahwa dilapangan masih banyak siswa yang cenderung merasa bosan, mengantuk karena guru yang masih menerapkan metode konvensional seperti ceramah dalam proses pembelajaran, sehingga menimbulkan siswa kurang berperan aktif dan kurangnya minat belajar. Permasalahan tersebut berdampak pada hasil belajar siswa yang rendah.

Berdasarkan latar belakang masalah yang telah diuraikan di atas, maka dapat disusun beberapa perumusan masalah sebagai berikut:

1. Apakah penerapan metode Pair Checks pada mata pelajaran Pendidikan Agama Islam (PAI) Sekolah Menengah Pertama (SMP) Negeri 3 Palimanan kabupaten Cirebon dapat diterapkan dengan baik?

2. Apakah hasil belajar siswa dengan Menggunakan metode Pair Checks pada mata pelajaran Pendidikan Agama Islam (PAI) Sekolah Menengah Pertama (SMP) Negeri 3 Palimanan Kabupaten Cirebon dikategorikan baik?

3. Seberapa besar pengaruh penerapan metode pembelajaran Pair Checks terhadap hasil belajar siswa pada mata pelajaran Pendidikan Agama Islam

\footnotetext{
${ }^{4}$ Mulyasa, Dkk. Revolusi dan Inovasi Pembelajaran (Bandung: PT Remaja Rosdakarya, 2016), 180.
}

Jurnal Pendidikan Agama Islam IAINSyekh Nurjati Cirebon 
(PAI) Sekolah Menengah Pertama (SMP) Negeri 3 Palimanan kabupaten Cirebon?

\section{B. LANDASAN TEORI}

\section{Metode Pair Checks}

Pair Checks adalah metode pembelajaran berkelompok antar dua atau berpasangan yang dipopulerkan oleh Spencer Kagen pada 1990. Model ini menerapkan pembelajaran kooperatif yang menuntut kemandirian dan kemampuan siswa dalam menyelesaikan persoalan. Metode ini juga melatih tanggung jawab sosial siswa, kerja sama, dan kemampuan memberi penilaian. ${ }^{5}$

\section{Hasil Belajar}

Nawawi dalam K.Brahim menyatakan bahwa hasil belajar dapat diartikan sebagai tingkat keberhasilan siswa dalam mempelajari materi pelajaran di sekolah yang dinyatakan dalam skor yang diperoleh dari hasil tes mengenai sejumlah materi pelajaran tertentu. ${ }^{6}$

\section{METODOLOGI PENELITIAN}

\section{Tempat dan Waktu Penelitian}

Penelitian ini dilaksanakan di Sekolah Menengah Pertama (SMP) Negeri 3 Palimanan Kabupaten Cirebon. Penelitian ini dilaksanakan selama dua bulan, sesuai dengan surat keputusan dari Fakultas Tarbiyah dan

${ }^{5}$ Miftahul Huda, Model-model Pengajaran dan Pembelajaran (Yogyakarta: Pustaka Belajar, 2014), 211.

${ }^{6}$ Ahmad Susanto, Teori Belajar Dan Pembelajaran (Jakarta: Prenada Media Group, 2016 ), 5.

Jurnal Pendidikan Agama Islam

IAIN Syekh Nurjati Cirebon 
Keguruan (FITK) Nomor: 1079/In.08/F.I.1/PP.009/02/2019 terhitung mulai tanggal 14 Februari sampai dengan 14 April 2019.

\section{Sumber Data, Jenis Data dan Desain Penelitian}

\section{a. Sumber Data}

1. Sumber data teoretik diperoleh dengan menelaah buku-buku perpustakaan dan sumber lain yang relevan dengan permasalahan dalam penelitian. Dalam hal ini peneliti menggunakan buku-buku yang berkenaan dengan penerapan Metode Pair Checks dan Hasil belajar siswa dan buku-buku pendukung lainnya. Buku buku yang dipakai sebagai referensi diantaranya Miftahul Huda dan Rusman.

2. Data empirik diperoleh melalui penelitian dengan menggunakan beberapa teknik penelitian yakni tes, wawancara, dan observasi yang dilakukan di Sekolah Menengah Pertama (SMP) Negeri 3 Palimanan Kabupaten Cirebon.

\section{Jenis Data}

Jenis data yang digunakan dalam penelitian ini adalah Jenis data yang bersifat kuantitatif. Data kuantitatif merupakan data yang di simbolkan berupa angka atau bilangan, sehingga bisa diinput ke dalam skala pengukuran statistik. $^{7}$

\section{Desain Penelitian}

Desain Penelitian adalah keseluruhan proses yang diperlukan dalam perencanaan dan pelaksanaan penelitian, sehingga pertanyaan-pertanyaan yang ada dapat dijawab. Adapun yang penulis gunakan dalam penelitian ini yaitu jenis penelitian eksperimen dengan menggunakan pendekatan

${ }^{7}$ Asep Kurniawan, Metodologi Penelitian Pendidikan (Cirebon: Eduvision), 171.

Jurnal Pendidikan Agama Islam

IAIN Syekh Nurjati Cirebon 
kuantitatif. Metode penelitian eksperimen berusaha menentukan apakah suatu treatment mempengaruhi hasil sebuah penelitian.Penelitian eksperimen yang dilakukan penulis disini adalah desain one-Group Pretest-Posttest Design, yakni dengan diberi pretest terlebih dulu sebelum diberi perlakuan, dan selanjutnya diobservasi hasilnya. Dengan demikian hasil perlakuan dapat diketahui lebih akurat, karena dapat membandingkan dengan keadaan sebelum diberi perlakuan. ${ }^{8}$

Pengumpulan data yang digunakan pada penelitian ini adalah observasi, angket, wawancara, tes, dan studi dokumentasi. Populasi dalam penelitian ini adalah kelas VIII yang berjumlah 292 siswa. Sementara sampel yang digunakan yaitu 32 siswa.

Teknik analisis data adalah suatu teknik yang diarahkan untuk menjawab rumusan masalah atau menguji hipotesis yang telah dirumuskan. Karena datanya kuantitatif, maka teknik analisis data menggunakan metode statistik. $^{9}$ Teknik analisis data yang digunakan adalah: Uji Validitas, Uji Reliabilitas, Uji Normalitas, prosentase, korelasi product moment, koefisien determinan, dan uji hipotesis.

\section{PEMBAHASAN}

\section{Metode Pair Checks}

Pair Checks diterjemahkan secara bebas, adalah "pasangan mengecek". Pair Checks (pasangan mengecek) adalah suatu metode pembelajaran yang memasangkan dalam rangka melatih rasa sosial peserta

\footnotetext{
${ }^{8}$ Sugiyono, Metode Penelitian Pendidikan (Pendekatan Kuantitatif, Kualitatif, dan $R \& D$ (Bandung: Alfabeta, 2015) 110.

${ }^{9}$ Sugiyono, Metode Penelitian Kuantitatif. 243.
}

Jurnal Pendidikan Agama Islam IAIN Syekh Nurjati Cirebon 
didik, kerja sama dan kemampuan memberi penilaian. ${ }^{10}$ Pair Checks adalah metode pembelajaran berkelompok antar dua atau berpasangan yang dipopulerkan oleh Spencer Kagen pada 1990. Model ini menerapkan pembelajaran kooperatif yang menuntut kemandirian dan kemampuan siswa dalam menyelesaikan persoalan. Metode ini juga melatih tanggung jawab sosial siswa, kerja sama, dan kemampuan memberi penilaian. ${ }^{11}$ Dalam metode Pair Checks guru bertindak sebagai motivator dan fasilitator aktivitas siswa.

Pada prinsipnya metode pembelajaran Pair Checks sangat mengedepankan teknik berpasang-pasangan dimana salah seorang menyajikan persoalan dan temannya mengerjakan, dan pengecekan kebenaran jawaban dilakukan dengan bertukar peran. ${ }^{12}$ Metode ini bertujuan untuk meningkatkan kemampuan siswa dalam menuangkan ide, pikiran, pengalaman, dan pendapatnya dengan benar. Dengan metode pair checks memungkinkan bagi siswa untuk saling bertukar pendapat dan saling memberikan saran.

Ada beberapa langkah dalam menerapkan Metode Pair Checks, diantaranya:

a. Guru menjelaskan konsep pembelajaran.

b. Siswa dibagi beberapa tim. Setiap tim terdiri dari 4 orang. Dalam satu tim ada 2 pasangan. Setiap pasangan dalam satu tim ada yang menjadi pelatih ada yang menjadi patner.

c. Guru membagikan soal kepada si patner.

${ }^{10}$ Karunia Eka Lestari dan Mokhammad Ridwan Yudhanegara, Penenlitian Pendidikan Matematika (Bandung: PT Refika Aditama, 2017) 74.

${ }^{11}$ Miftahul Huda, Model-model Pengajaran dan Pembelajaran (Yogyakarta: Pustaka Belajar, 2014), 211.

12 Imas Kurniasih dan Sani Berlin, Ragam Pengembangan Model Pembelajaran untuk Peningkatan profesionalitas guru (Jogjakarta: Kata pena, 2015), 112.

Jurnal Pendidikan Agama Islam IAIN Syekh Nurjati Cirebon 
d. Patner menjawab soal, dan si pelatih bertugas mengecek jawabannya. Setiap soal yang benar pelatih memberi kupon.

e. Bertukar peran. Si pelatih menjadi patner dan si patner menjadi pelatih.

f. Guru membagikan soal kepada si patner.

g. Patner menjawab soal, dan si pelatih bertugas mengecek jawabannya. Setiap soal yang benar pelatih memberi kupon.

h. Setiap pasangan kembali ke tim awal dan mencocokkan jawaban satu sama lain.

i. Guru membimbing dan memberikan arahan atas jawaban dari berbagai soal dan tim mengecek jawabannya.

j. Tim yang paling banyak mendapat kupon diberi hadiah. ${ }^{13}$

\section{Hasil Belajar}

Nawawi dalam K.Brahim menyatakan bahwa hasil belajar dapat diartikan sebagai tingkat keberhasilan siswa dalam mempelajari materi pelajaran di sekolah yang dinyatakan dalam skor yang diperoleh dari hasil tes mengenai sejumlah materi pelajaran tertentu. ${ }^{14}$ Hasil belajar dapat terlihat dari terjadinya perubahan dari persepsi dan perilaku, termasuk juga perbaikan perilaku". ${ }^{15}$

Pada umumnya hasil belajar dapat dikelompokkan menjadi tiga macam ranah, yaitu afektif (sikap), kognitif (pengetahuan), dan psikomotorik (keterampilan). ${ }^{16}$ Indikator utama hasil belajar siswa adalah sebagai berikut:

\footnotetext{
${ }^{13}$ Imas Kurniasih dan Sani Berlin, Ragam Pengembangan Model Pembelajaran 112. ${ }^{14}$ Ahmad Susanto, Teori Belajar Dan Pembelajaran (Jakarta: Prenada Media Group, 2016), 5.

${ }^{15}$ Rusman, Belajar Pembelajaran Berorientasi Standar Proses Pendidikan (Jakarta: Kencana, 2017), 129.

${ }^{16}$ Elis Ratnawulan, Evaluasi Pembelajaran (Bandung: CV Pustaka Setia, 2015), 57.
}

Jurnal Pendidikan Agama Islam IAINSyekh Nurjati Cirebon 
a. Ketercapaian daya serap terhadap pahan pembelajaran yang diajarkan, baik secara individual maupun kelompok. Pengukuran ketercapaian daya serap ini biasana dilakukan dengan penetapan kriteria Ketuntasan Belajar Minimal (KKM).

b. Perilaku yang digariskan dalam tujuan pengajaran/intruksional khusus (TIK) telah dicapai oleh siswa, baik secara individual maupun kelompok. ${ }^{17}$

Sebelum menganalisis data hasil penelitian menggunakan data angket, penulis mengajukan angket kepada 32 siswa sebagai responden, dengan alternative jawaban :

\begin{tabular}{|l|c|}
\hline \multicolumn{1}{|c|}{ Alternative Jawaban } & Skor \\
\hline Selalu (SL) & 4 \\
\hline Sering (SR) & 3 \\
\hline Kadang-kadang (KK) & 2 \\
\hline Tidak Pernah (TP) & 1 \\
\hline
\end{tabular}

Angket yang disebarkan kepada responden untuk mengukur variabel yang diteliti yakni variabel x (Pengaruh penerapan metode Pair Checks), pernyataan dalam angket berjumlah 25 sedangkan variabel Y(Hasil Belajar Siswa) menggunakan tes (soal pilihan ganda berjumlah 20 dan soal essai berjumlah 5). Data yang akan dianalisis terlebih dahulu dilakukan pengujian prasyarat dengan menggunakan uji Validitas, Reabilitas, dan Normalitas. Selanjutnya setelah penyebaran angket dan tes maka data akan dianalisis, dan akan diketahui apakah variabel x mempengaruhi variabel y atau tidak. Dari

${ }^{17}$ Saiful Bahri Djamarah dan Aswan Zaen, Strategi Belajar Mengajar (Jakarta: Rineka Cipta, 2014), 106. 
penyebaran angket dan soal tes didapatkan data yang akan dianalisis dengan Uji Statistik menggunakan SPSS V.21 berikut ini:

\section{a. Uji Validitas}

\section{Hasil Uji Validitas Angket Metode Pair Checks}

\begin{tabular}{|l|c|c|c|}
\hline $\begin{array}{l}\text { No } \\
\text { Item }\end{array}$ & $\boldsymbol{r}$ hitung & $\begin{array}{c}\text { rtabel } \\
(\text { Sig5\% })\end{array}$ & Keterangan \\
\hline 1 & 0,398 & 0,361 & Valid \\
\hline 2 & 0,505 & 0,361 & Valid \\
\hline 3 & 0,470 & 0,361 & Valid \\
\hline 4 & 0,431 & 0,361 & Valid \\
\hline 5 & 0,405 & 0,361 & Valid \\
\hline 6 & 0,449 & 0,361 & Valid \\
\hline 7 & 0,482 & 0,361 & Valid \\
\hline 8 & 0,401 & 0,361 & Valid \\
\hline 9 & 0,457 & 0,361 & Valid \\
\hline 10 & 0,438 & 0,361 & Valid \\
\hline 11 & 0,390 & 0,361 & Valid \\
\hline 12 & 0,478 & 0,361 & Valid \\
\hline 13 & 0,471 & 0,361 & Valid \\
\hline 14 & 0,387 & 0,361 & Valid \\
\hline 15 & 0,513 & 0,361 & Valid \\
\hline
\end{tabular}

Jurnal Pendidikan Agama Islam IAIN Syekh Nurjati Cirebon 


\begin{tabular}{|l|c|c|c|}
\hline $\begin{array}{l}\text { No } \\
\text { Item }\end{array}$ & $\boldsymbol{r}$ hitung & $\begin{array}{c}\text { r tabel } \\
(\text { Sig5\% })\end{array}$ & Keterangan \\
\hline 16 & 0,409 & 0,361 & Valid \\
\hline 17 & 0,387 & 0,361 & Valid \\
\hline 18 & 0,499 & 0,361 & Valid \\
\hline 19 & 0,402 & 0,361 & Valid \\
\hline 20 & 0,454 & 0,361 & Valid \\
\hline 21 & 0,392 & 0,361 & Valid \\
\hline 22 & 0,562 & 0,361 & Valid \\
\hline 23 & 0,468 & 0,361 & Valid \\
\hline 24 & 0,416 & 0,361 & Valid \\
\hline 25 & 0,486 & 0,361 & Valid \\
\hline
\end{tabular}

Berdasarkan hasil uji validitas angket di atas bahwasanya 25 item angket masing-masing Variabel dinyatakan valid karena $r_{\text {hitung }}$ dari setiap item $>r_{\text {tabel }}(0,361)$.

\section{b. Uji Reliabilitas}

\section{Hasil Uji Reabilitas Angket Metode Pair Checks}

Reliability Statistics

\begin{tabular}{|c|c|}
\hline $\begin{array}{c}\text { Cronbach's } \\
\text { Alpha }\end{array}$ & N of Items \\
\hline .830 & 25 \\
\hline
\end{tabular}


Pada tabel Reliability Statistis diperoleh nilai sebesar 0,830 Cronbach's Alpha, sedangkan nilai $r_{\text {tabel }}$ pada signifikan 0,05 dengan jumlah data $(\mathrm{n})=32$ diperoleh sebesar 0,361. Dikarenakan Cronbach's Alpha $(0,830)>r$ tabel $(0,361)$, maka dapat disimpulkan bahwa angket variabel $\mathrm{X}$ dinyatakan reliabel dengan kategori reliabel sangat tinggi, karena berada pada interprtasi $0,81 \leq \mathrm{r} \leq 1,00$ dan instrumen tersebut dapat digunakan sebagai alat pengumpul data.

\section{c. Uji Normalitas}

\section{Hasil Uji Normalitas}

\section{One-Sample Kolmogorov-Smirnov Test}

\begin{tabular}{|l|l|r|r|}
\hline \multicolumn{2}{|l|}{} & \multicolumn{1}{|c|}{$\mathrm{X}$} & \multicolumn{1}{|c|}{$\mathrm{Y}$} \\
\hline $\mathrm{N}$ & & 32 & 32 \\
\hline \multirow{3}{*}{ Normal Parameters ${ }^{\mathrm{a}, \mathrm{b}}$} & Mean & 84.6875 & 81.5313 \\
\cline { 2 - 4 } & Std. Deviation & 8.04999 & 6.38033 \\
\hline \multirow{3}{*}{ Most Extreme Differences } & Absolute & .176 & .165 \\
\cline { 2 - 4 } & Positive & .114 & .131 \\
\cline { 2 - 4 } & Negative & -.176 & -.165 \\
\hline Kolmogorov-Smirnov Z & & .993 & .933 \\
\hline Asymp. Sig. (2-tailed) & .278 & .349 \\
\hline a. Test distribution is Normal. & \\
\hline \multicolumn{2}{|l}{} \\
\hline b. Calculated from data.
\end{tabular}

Hipotesis:

$\mathrm{H}_{\mathrm{o}}$ : Data berdistribusi normal

$\mathrm{H}_{\mathrm{a}}$ : Data berdistribusi tidak normal 
Kriteria pengujian:

Jika probabilitas (Sig.) > 0,05, $\mathrm{H}_{\mathrm{o}}$ diterima, artinya datanya normal.

Jika probabilitas (Sig.) $<0,05, \mathrm{H}_{\mathrm{o}}$ ditolak, artinya data tidak normal.

Berdasarkan hasil uji normalitas diperoleh nilai sig. N-gain Penerapan metode Pair Checks (variabel X) dengan uji KolmogorovSmirnov diperoleh 0,278 berada di atas 0,05 , dengan demikian Ho diterima dan $\mathrm{H}_{\mathrm{a}}$ ditolak, artinya data tersebut berdistribusi normal. Dan Sig. Hasil Belajar (variabel Y) diperoleh 0,349 yang berada di atas 0.05. Dengan demikian Ho diterima dan Ha ditolak, artinya data tersebut berasal dari populasi yang berdistribusi normal. Setelah dilakukan uji persyarat dan penyebaran angket kepada 32 responden, selanjutnya data akan dianalisis dan diuji hipotesisnya. Di bawah ini akan dipaparkan mengenai analisis hasil penelitiannya.

1) Analisis Data Hasil Angket Penerapan Metode Pair Checks

Berdasarkan hasil angket di atas, akan dicari seberapa besar prosentase pengaruh metode Pair Checks (skor Variabel X) dengan menggunakan rumus sebagai berikut:

$$
\frac{S O}{S T} \times 100 \%
$$

Keterangan :

$$
\begin{array}{ll}
\text { SO }(\text { Skor Observasi) } & =\text { Jumlah skor variabel } \mathrm{X} \\
\text { ST }(\text { Skor Total }) & =\mathrm{N} \times \text { jumlah pertanyaan } \times \text { jumlah option } \\
\text { Diketahui } & =\mathrm{SO}=2710 \\
& \mathrm{ST}=32 \times 25 \times 4=3200 \\
= & \frac{2710}{3200} \times 100 \%
\end{array}
$$

Jurnal Pendidikan Agama Islam

IAIN Syekh Nurjati Cirebon 


$$
=84,69 \%
$$

Berdasarkan rekapitulasi hasil penghitungan angket di atas mengenai Penerapan metode Pair Checks adalah 84,69\%, ini artinya berada pada rentang prosentase $76 \%$ - 100\% termasuk dalam kategori Baik.

2) Analisis Data Hasil Belajar Siswa

Hasil Belajar Siswa menunjukkan bahwa dari jumlah 32 siswa kelas VIII C sebanyak 29 siswa mendapat nilai yang sesuai dan diatas KKM (Kriteria Ketuntasan Minimum), dan hanya ada 3 siswa yang nilainya dibawah KKM. Sedangkan KKM Mata Pelajaran Pendidikan Agama Islam (PAI) adalah 73.

Berdasarkan rekapitulasi hasil belajar siswa kelas VIII C mata Pelajaran pendidikan Agama Islam (PAI) SMP Negeri 3 Palimanan kabupaten Cirebon dengan nilai rata-rata 81,5 berada pada rentang prosentase antara 75\% - 100\%. termasuk dalam kategori Baik.

3) Untuk mencari Pengaruh Penerapan Metode Pair Checks terhadap

Hasil Belajar Siswa kelas VIII C mata Pelajaran pendidikan Agama Islam (PAI) SMP Negeri 3 Palimanan kabupaten Cirebon dengan menggunakan rumus product moment sebagai berikut:

\begin{tabular}{|c|c|c|c|c|c|}
\hline No & $\mathbf{X}$ & $\mathbf{Y}$ & $\boldsymbol{X}^{\mathbf{2}}$ & $\mathbf{Y}^{\mathbf{2}}$ & $\mathbf{X Y}$ \\
\hline 1. & 94 & 82 & 8836 & 6724 & 7708 \\
\hline 2. & 82 & 92 & 6724 & 8464 & 7544 \\
\hline 3. & 73 & 90 & 5329 & 8100 & 6570 \\
\hline 4. & 72 & 84 & 5184 & 7056 & 6048 \\
\hline 5. & 81 & 78 & 6561 & 6084 & 6318 \\
\hline 6. & 69 & 82 & 4761 & 6724 & 5658 \\
\hline 7. & 91 & 70 & 8281 & 4900 & 6370 \\
\hline 8. & 83 & 68 & 6889 & 4624 & 5644 \\
\hline
\end{tabular}

\section{Jurnal Pendidikan Agama Islam} IAIN Syekh Nurjati Cirebon 


\begin{tabular}{|c|c|c|c|c|c|}
\hline 9. & 89 & 82 & 7921 & 6724 & 7298 \\
\hline 10. & 89 & 82 & 7921 & 6724 & 7298 \\
\hline 11. & 90 & 80 & 8100 & 6400 & 7200 \\
\hline 12. & 90 & 80 & 8100 & 6400 & 7200 \\
\hline 13. & 95 & 92 & 9025 & 8464 & 8740 \\
\hline 14. & 81 & 68 & 6561 & 4624 & 5508 \\
\hline 15. & 88 & 86 & 7744 & 7396 & 7568 \\
\hline 16. & 94 & 84 & 8836 & 7056 & 7896 \\
\hline 17. & 94 & 84 & 8836 & 7056 & 7896 \\
\hline 18. & 87 & 78 & 7569 & 6084 & 6786 \\
\hline 19. & 82 & 84 & 6724 & 7056 & 6888 \\
\hline 20. & 92 & 80 & 8464 & 6400 & 7360 \\
\hline 21. & 71 & 78 & 5041 & 6084 & 5538 \\
\hline 22. & 89 & 81 & 7921 & 6561 & 7209 \\
\hline 23. & 73 & 84 & 5329 & 7056 & 6132 \\
\hline 24. & 87 & 84 & 7569 & 7056 & 7308 \\
\hline 25. & 90 & 78 & 8100 & 6084 & 7020 \\
\hline 26. & 83 & 70 & 6889 & 4900 & 5810 \\
\hline 27. & 77 & 84 & 5929 & 7056 & 6468 \\
\hline 28. & 92 & 86 & 8464 & 7396 & 7912 \\
\hline 29. & 70 & 78 & 4900 & 6084 & 5460 \\
\hline 30. & 95 & 80 & 9025 & 6400 & 7600 \\
\hline 31. & 88 & 90 & 7744 & 8100 & 7920 \\
\hline 32. & 91 & 80 & 8281 & 6400 & 7280 \\
\hline 33. & 79 & 92 & 6241 & 8464 & 7268 \\
\hline 34. & 93 & 84 & 8649 & 7056 & 7812 \\
\hline 35 & 89 & 80 & 7921 & 6400 & 7120 \\
\hline Jml & 2710 & 2609 & 231512 & 213977 & 220961 \\
\hline
\end{tabular}

$$
\frac{N \sum X Y-\left(\sum X\right)\left(\sum Y\right)}{\sqrt{\left\{N \cdot \sum X^{2}-\left(\sum X\right)^{2}\right\}\left\{N \sum Y^{2}-\left(\sum Y\right)^{2}\right\}}}
$$

Keterangan:

$\mathrm{r}_{\mathrm{xy}}=$ Koefisien korelasi antara variable $\mathrm{X}$ dan $\mathrm{Y}$

\section{Jurnal Pendidikan Agama Islam IAIN Syekh Nurjati Cirebon}




$$
\begin{aligned}
& \mathrm{N} \quad=\text { Jumlah sampel } \\
& \sum X Y=\text { Jumlah hasil perkalian antara skor } \mathrm{X} \text { dan skor } \mathrm{Y} \\
& \sum X \quad=\text { Jumlah skor variabel } X \\
& \sum Y \quad=\text { Jumlah skor variabel } \mathrm{Y} \\
& \sum x^{2}=\text { Jumlah kuadrat skor variabel } \mathrm{X} . \\
& \sum y^{2}=\text { Jumlah kuadrat skor variabel } \mathrm{Y}^{18} \\
& r_{x y}=\frac{32.220961-(7070390)}{\sqrt{\{32.231512-(7344100)\}\{32.213977-6806881\}}} \\
& r_{x y}=\frac{7070752-7070390}{\sqrt{\{7408384-(7344100)\}\{6847264-6806881\}}} \\
& r_{x y}=\frac{7070752-7070390}{\sqrt{\{64284\}\{40383\}}} \\
& r_{x y}=\frac{362}{\sqrt{\{2595980772\}}} \\
& r_{x y}=\frac{362}{5095076811} \\
& r_{x y}=0,71049072 \\
& r_{x y}=0,710
\end{aligned}
$$

Berdasarkan perhitungan di atas, diperoleh angka korelasi sebesar 0,710 yang berarti korelasi tersebut bersifat positif, dapat dinyatakan pada kriteria korelasi yang kuat/tinggi karena pada interval 0,70 - 0,90.

${ }^{18}$ Anas Sudijono, Pengantar Evaluasi Pendidikan (Jakarta: Rajawali Pers, 2011), 206. 
Sehingga kita dapat menginterpretasikan yaitu terdapat hubungan antara variabel $X$ (Penerapan Metode Pair Checks) dengan variabel Y (Hasil Belajar). Kemudian untuk mengetahui seberapa besar pengaruh variabel $\mathrm{X}$ dan variabel $\mathrm{Y}$, maka dapat dihitung dengan menggunakan rumus koefisien determinasi, yaitu : $\mathrm{KD}=\mathrm{rx}^{2} \mathrm{x} 100 \%{ }^{19}$

$$
\begin{aligned}
& \mathrm{KD}=\left(r_{x y}\right)^{2} \quad \mathrm{x} \quad 100 \% \\
& =(0,71)^{2} \times 100 \% \\
& =0,5041 \times 100 \% \\
& =50,41 \%
\end{aligned}
$$

Dapat disimpulkan bahwa, Hasil Belajar ditentukan atau dipengaruhi oleh penerapan Metode Pair Checks sebesar 50,41 \% Maka 49,59 \% lagi ditentukan oleh faktor lain yang tidak diteliti dalam penelitian ini. Selanjutnya untuk mengetahui $r_{x y}$ signifikansi atau tidak dengan mengkonsultasikannya pada tabel distribusi “ $t$ ”. Adapun rumusnya yaitu :

$$
\begin{aligned}
t_{\text {hitung }} & =\frac{r \sqrt{n-2}}{\sqrt{1-r^{2}}} \\
& =\frac{0,71 \sqrt{32-2}}{\sqrt{1-(0,662)^{2}}} \\
& =\frac{0,71 \sqrt{30}}{\sqrt{1-0,5041}} \\
& =\frac{0,71 \cdot(5,477)}{\sqrt{0,4959}}
\end{aligned}
$$

${ }^{19}$ Riduwan Dan Sunarto, Pengantar Statistika (Bandung: Alfabeta, 2009), 80.

$$
\begin{aligned}
& \text { Jurnal Pendidikan Agama Islam } \\
& \text { IAIN Syekh Nurjati Cirebon }
\end{aligned}
$$




$$
\begin{aligned}
& =\frac{3888,67}{0,704} \\
& =5,524
\end{aligned}
$$

Menacari $\mathrm{t}_{\text {tabel }} a=0,05$ atau $5 \%$

$$
\begin{aligned}
\mathrm{df} & =(\mathrm{n}-2)=32-2=30 \\
30 & =1,697
\end{aligned}
$$

Maka, $t_{\text {hitung }}=5,524>\mathrm{t}_{\text {tabel }}=1,697$

Kaidah pengujian :

1) Jika $t$ hitung $\geq \mathrm{t}$ table berarti signifikan

2) Jika t hitung $\leq \mathrm{t}$ tabel berarti tidak signifikan

Berdasarkan perhitungan diatas, dapat disimpulkan bahwa Perolehan nilai " $t$ " tersebut dengan $\mathrm{df}=32-2=30$ didapat $t_{\text {tabel }}=1,697$ pada taraf signifikan $a=0,05$ sedangkan nilai $t_{\text {hitung }}=5,524$. Oleh karena itu, thitung $>$ $\mathrm{t}_{\text {tabel, }}$ yaitu 5,524>1,697. berdasarkan kaidah diatas artinya terdapat pengaruh yang signifikan antara Penerapan Metode Pair Checks Terhadap Hasil Belajar Pada Mata Pelajaran Pendidikan Agama Islam (PAI) Sekolah Menengah Pertama (SMP) Negeri 3 Palimanan Kabupaten Cirebon.

\section{E. KESIMPULAN}

Berdasarkan penelitian, maka peneliti dapat mengambil beberapa kesimpulan yaitu sebagai berikut

1. Berdasarkan rekapitulasi rata-rata hasil angket variabel $X$ terkait penerapan metode Pair Checks, pada Mata Pelajaran pendidikan Agama Islam (PAI) Siswa kelas VIII C SMP Negeri 3 Palimanan kabupaten Cirebon termasuk dalam kategori Baik, dengan nilai rata-rata 84,69\% karena berada pada rentang prosentase antara $75 \%-100 \%$.

\section{Jurnal Pendidikan Agama Islam} IAIN Syekh Nurjati Cirebon 
2. Hasil belajar siswa pada mata Pelajaran pendidikan Agama Islam (PAI) kelas VIII C SMP Negeri 3 Palimanan kabupaten Cirebon termasuk dalam kategori Baik, dengan nilai rata-rata 81,5 karena berada pada rentang prosentase antara $75 \%-100 \%$.

3. Pengaruh penerapan Metode Pair Checks dengan hasil belajar siswa pada mata Pelajaran pendidikan Agama Islam (PAI) siswa kelas VIII C SMP Negeri 3 Palimanan kabupaten Cirebon menunjukkan nilai korelasi yang mencapai $\mathbf{r}_{\mathbf{x y}}=$ 0,710 yang menunjukkan pada korelasi yang kuat/tinggi, karena berada pada interval 0,700 - 0,900. Menunjukkan hubungan yang Signifikan antara penerapan metode Pair Checks (variabel X) dengan hasil belajar (variabel Y). Adapun besaran pengaruhnya adalah 50,41 \% dan 49,59 \% sisanya lagi dipengaruhi oleh faktor lain yang tidak diteliti dalam penelitian ini. Adapun nilai uji $\mathrm{T}$ diperoleh $\mathrm{t}_{\text {hitung }}>\mathrm{t}_{\text {tabel }}$ atau $\mathrm{t}_{\text {hitung }}=5,524>\mathrm{t}_{\text {tabel }}=1,697$ sehingga di nyatakan adanya pengaruh yang signifikan antara penerapan metode Pair Checks terhadap hasil belajar siswa pada mata Pelajaran pendidikan Agama Islam (PAI) kelas VIII C SMP Negeri 3 Palimanan kabupaten Cirebon.

\section{DAFTAR PUSTAKA}

Dirman dan Cicih Juarsih. 2014. Kegiatan Pembelajaran yang Mendidik. Jakarta: PT Rineka Cipta.

Djamarah, Saiful Bahri dan Aswan Zaen. 2014. Strategi Belajar Mengajar. Jakarta: Rineka Cipta.

Helmiati. 2012 Model Pembelajaran. Yogyakarta: Aswaja Pressindo.

\footnotetext{
Jurnal Pendidikan Agama Islam IAIN Syekh Nurjati Cirebon
} 
Huda, Miftahul. 2014. Model-model Pengajaran dan Pembelajaran. Yogyakarta: Pustaka Belajar.

Kurniasih, Imas dan Sani Berlin. 2015. Ragam Pengembangan Model Pembelajaran untuk Peningkatan profesionalitas guru. Jogjakarta: Kata pena.

Kurniawan, Asep. 2018. Metodologi Penelitian Pendidikan. Cirebon: Eduvision

Lestari, Karunia Eka Lestari dan Mokhammad Ridwan Yudhanegara. 2017. Penelitian Pendidikan Matematika. Bandung: PT. Refika Aditama.

Mulyasa, Dkk. 2016. Revolusi dan Inovasi Pembelajaran. Bandung: PT Remaja Rosdakarya

Ratnawulan, Elis. Dan Rusdiana. 2015. Evaluasi Pembelajaran. Bandung: CV Pustaka Setia.

Riduwan Dan Sunarto. 2009. Pengantar Statistika. Bandung: Alfabeta

Rusman. 2017. Belajar Pembelajaran Berorientasi Standar Proses Pendidikan. Jakarta: Kencana

Shoimin, Aris. 2017. 68 Model Pembelajaran Inovatif dalam Kurikulum 2013. Yogyakarta: Ar-Ruzz Media.

Sudijono, Anas. 2011. Pengantar Evaluasi Pendidikan. Jakarta: Rajawali Pers

Sugiyono. 2015. Metode Penelitian Pendidikan (Pendekatan Kuantitatif, Kualitatif, dan $R \& D)$. Bandung: Alfabeta

Susanto, Ahmad. 2016. Teori Belajar Dan Pembelajaran. Jakarta: Prenada Media Group

Sugiyono. 2017. Metode Penelitian Kuantitatif, Kualitatif, dan R\&D. Bandung: Alfabeta.

\footnotetext{
Jurnal Pendidikan Agama Islam

IAIN Syekh Nurjati Cirebon
} 